\title{
Alat Sortir Biji Kopi Berbasis Metode Getaran Menggunakan Arduino Due
}

\author{
Dandi Zulfikar Azis, Muhammad Rivai \\ Departemen Teknik Elektro, Fakultas Teknologi Elektro \\ Institut Teknologi Sepuluh Nopember (ITS) \\ e-mail: muhammad_rivai@ee.its.ac.id
}

\begin{abstract}
Abstrak-Ukuran biji kopi yang tidak seragam pada saat proses sangrai mengakibatkan tingkat kematangan biji kopi tidak merata. Jika proses tersebut terus dilanjutkan hingga menjadi bubuk kopi siap saji, hal itu sangat mempengaruhi kualitasnya. Penelitian ini mengimplementasikan alat sortir biji kopi dengan menggunakan getaran sebagai pengayaknya yang bertujuan untuk klasifikasi ukuran biji kopi agar proses sangrai dapat lebih merata. Alat sortir ini dilengkapi dengan motor getar sebagai sumber getaran yang digunakan, sensor percepatan ADXL345 sebagai monitor dan kendali getaran yang dihasilkan, sensor berat (Load Cell) sebagai monitoring berat total biji kopi yang sedang diayak. Hasil penelitian menunjukkan bahwa perubahan kecepatan motor getar sebanding dengan perubahan getaran yang dihasilkan dan berat beban yang diampu berbanding terbalik dengan getaran yang dihasilkan. Pada penelitian ini, proses kendali getaran dengan mengendalikan kecepatan motor getar yang memiliki setpoint getaran $\pm 3 \mathrm{~m} / \mathrm{s}^{2}$ menghasilkan getaran yang cukup stabil. Hasil implementasi alat sortir biji kopi ini dapat bekerja dengan baik, yaitu dapat melakukan proses sortasi biji kopi dengan berat 2 $\mathrm{Kg}$ dapat meloloskan total biji kopi sebesar 1,91 - 1,95 Kg, dengan tingkat error akhir pada biji kopi ukuran besar sebesar 1,91 - 2,24 \% dan tingkat error pada biji kopi ukuran sedang sebesar $1,14-1,46 \%$.
\end{abstract}

Kata Kunci-ADXL345, Load Cell, Motor Getar, Sortasi Biji Kopi, Ukuran Biji Kopi.

\section{PENDAHULUAN}

K OPI merupakan komoditas perdagangan internasional terbesar kedua setelah minyak bumi, dan Indonesia adalah negara pengekspor kopi terbesar keempat setelah Brazil, Vietnam dan Kolombia[1]. Namun, banyaknya petani kopi yang kurang akan pengetahuan bagaimana cara mengolah biji kopi yang baik dan benar akan berdampak terhadap turunnya kualitas kopi yang dihasilkan dan mengurangi kepercayaan konsumen terhadap produk kopi asli Indonesia.

Menurut data dari BPS (Badan Pusat Statistik), jumlah penduduk pada tahun 2016-2020 diperkirakan akan meningkat setiap tahunnya. Dengan demikian permintaan rumah tangga di Indonesia akan kopi meningkat setiap tahunnya sejalan dengan peningkatan jumlah penduduk Indonesia[2].

Karena perawatan diperlukan untuk mendapatkan cita rasa yang optimal dari produk akhir, sistem pemantauan kualitas bahan baku menjadi peran utama dalam pengolahan kopi[3]. Atas dasar tersebut muncul suatu ide untuk membuat suatu alat yang dapat memilah biji kopi berdasarkan ukurannya. Hal ini bertujuan untuk mengklasifikasikan ukuran biji kopi tersebut. Jika biji kopi memiliki keseragaman dalam ukuran, berat, dan kelembapan, maka proses pemanggangan akan relatif lebih mudah untuk dilakukan. Tingkat kematangan biji kopi panggang menciptakan berbagai rasa dan aroma dalam minuman kopi[4],[5].

Adapun klasifikasi ukuran biji kopi tersebut menurut SNI (Standar Nasional Indonesia), yaitu untuk biji kopi robusta pengolahan basah memiliki diameter lebih dari 7,5 mm untuk ukuran besar, 6,5 - 7,5 mm untuk ukuran sedang, 5,5 - 6,5 mm untuk ukuran kecil[3].

Direncanakan alat sortasi ini khusus digunakan untuk biji kopi jenis robusta. Desain alat menggunakan 3 buah wadah alumunium yang disusun secara bertingkat. Setiap wadah memiliki lubang-lubang dengan diameter yang berbeda yaitu 7,5 mm, 6,5 mm, dan 5,5 mm. Dengan memanfaatkan metode getaran (pengayakan) diharapkan biji kopi tersebut dapat terpisah dengan efisiensi yang tinggi. Adapun sumber getaran menggunakan motor getar. Sensor akselero ADXL345 digunakan untuk mengontrol percepatan dari getaran tersebut dan sensor Load Cell untuk memonitoring biji kopi selama proses pengayakan.

\section{METODE PENELITIAN}

\section{A. Standar Mutu Biji Kopi Robusta}

Standar mutu pada kopi sangat penting sebagai bentuk petunjuk pengawasan mutu serta sebagai kontrol kualitas. Hal ini diperlukan guna untuk menghadapi rasa ketidakpuasan dari konsumen. Syarat mutu khusus biji kopi robusta pengolahan basah sesuai dengan SNI No. 01-2907-2008 ditunjukkan pada Tabel 1.

Tabel 1.

Syarat mutu khusus kopi robusta pengolahan basah[3].

\begin{tabular}{|c|c|c|c|}
\hline Ukuran & Kriteria & Satuan & Persyaratan \\
\hline Besar & $\begin{array}{l}\text { Tidak lolos ayakan } \\
\text { berdiameter 7,5 mm (Sieve } \\
\text { No.19) }\end{array}$ & $\begin{array}{l}\% \text { fraksi } \\
\text { massa }\end{array}$ & $\begin{array}{l}\text { Maks lolos } \\
5 \%\end{array}$ \\
\hline Sedang & $\begin{array}{l}\text { Lolos ayakan diameter 7,5 } \\
\text { mm, tidak lolos ayakan } \\
\text { berdiameter 6,5 mm (Sieve } \\
\text { No.16) }\end{array}$ & $\begin{array}{l}\% \text { fraksi } \\
\text { massa }\end{array}$ & $\begin{array}{l}\text { Maks lolos } \\
5 \%\end{array}$ \\
\hline Kecil & $\begin{array}{l}\text { Lolos ayakan diameter } 6,5 \\
\text { mm, tidak lolos ayakan } \\
\text { berdiameter } 5,5 \text { mm (Sieve } \\
\text { No. } 14 \text { ) }\end{array}$ & $\begin{array}{l}\% \text { fraksi } \\
\text { massa }\end{array}$ & $\begin{array}{l}\text { Maks lolos } \\
5 \%\end{array}$ \\
\hline
\end{tabular}

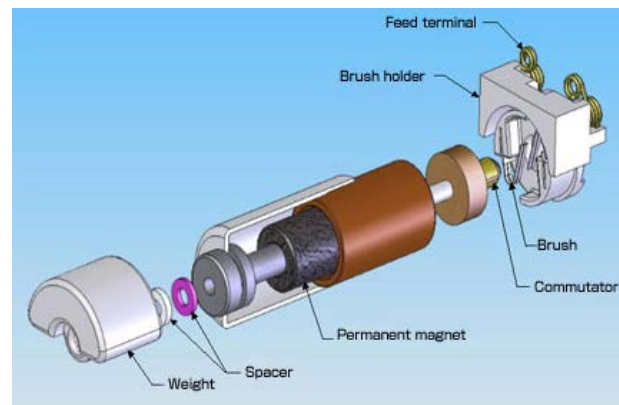

Gambar 1. Struktur motor getar[6]. 


\section{B. Motor Getar}

Gambar 1 merupakan konstruksi yang ada pada motor getar. Motor getar ini pada dasarnya motor DC yang tidak seimbang. Dengan kata lain, berat yang tidak seimbang menempel pada poros rotasi motor menghasilkan gaya sentrifugal ketika berputar dan mengakibatkan pergeseran pada motor. Perpindahan kecepatan yang tinggi membuat motor bergetar [6].

Getaran dapat diubah dengan mengubah berat yang dipasang, jarak beban ke poros, dan kecepatan motor. Gaya sentrifugal dihasilkan dari beban tidak seimbang yang berotasi dapat dihitung melalui persamaan berikut[6]:

Frekuensi getaran:

Gaya getaran:

$$
\text { fgetaran }=\frac{\text { motor } R P M}{60}
$$

$$
\text { Fgetaran }=m \cdot r \cdot \omega^{2}
$$

dimana $m$ adalah massa berat eksentrik, $r$ adalah jarak massa, $\omega$ adalah kecepatan motor $\left(\operatorname{rads}^{-1}\right)$ yang dinyatakan [6]:

$$
\omega=2 \pi f
$$

\section{Sensor ADXL345}

Merupakan sensor gerak atau akselerasi 3 sumbu yang memiliki resolusi 13-bit (8194 tingkat presisi). Sensor ini dapat mendeteksi tarikan pada jangkauan hingga 16g (16 x $9,81 \mathrm{~m} / \mathrm{s}^{2} \sim \pm 157 \mathrm{~m} / \mathrm{s}^{2}$ ) [7]. Sensor ini memiliki prinsip kerja MEMS yaitu sensor mekanik yang dikemas dalam bentuk IC. Pegas dibuat dengan pelat mini yang ujungnya diberi penyangga dan di tengahnya diberi beban dan plat dipasang dalam posisi berhadapan. Pada percepatan getaran tertentu akan mengakibatkan perubahan nilai kapasitansi yang mengakibatkan tegangan output dari sensor ini berubah[8],[9]. Gambar 2 merupakan diagram blok ADXL345.

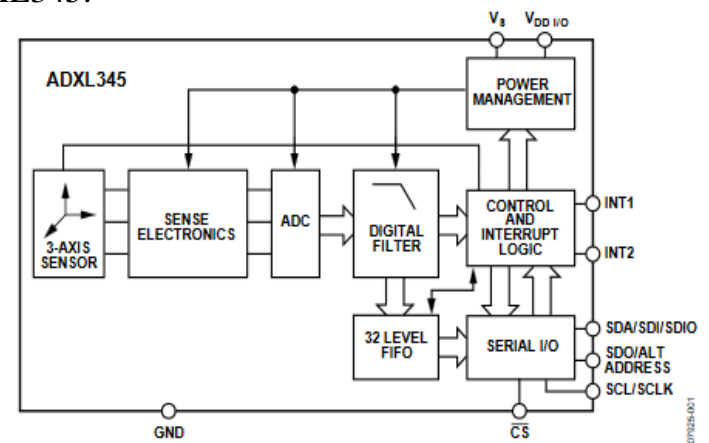

Gambar 2. Diagram blok ADXL345[7].
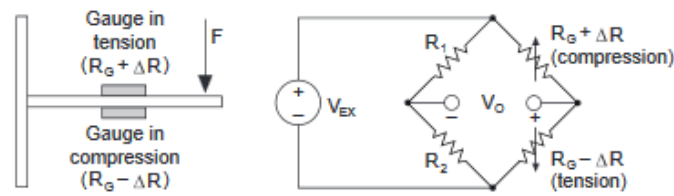

Gambar 3. Rangkaian Half-Bridge.

\section{Load Cell}

Pada gambar 3 mengilustrasikan konfigurasi Half-bridge ke sebuah balok lentur dengan satu buah bridge yang dipasang pada tegangan (tension) $\mathrm{R}_{\mathrm{G}}+\Delta \mathrm{R}$ dan pada sisi yang berlawanan dipasang secara kompresi (compression) $\mathrm{R}_{\mathrm{G}}-$ $\Delta \mathrm{R}$. Dari konfigurasi tersebut maka diperoleh persamaa:

$$
V o=\left[\frac{R 3}{R 3+R 4}-\frac{R 2}{R 1-R 2}\right] . V e x
$$

Biasanya konfigurasi ini diterapkan pada beberapa jenis sensor berat atau yang sering disebut sebagai load cell.
Adapun untuk sebagian load cell juga menerapkan konfigurasi quarter-bridge atau full-bridge[10].

\section{PERANCANGAN SISTEM}

\section{A. Desain Mekanik Sistem}

Desain mekanik sistem ini dibagi menjadi beberapa bagian, yaitu desain untuk beban eksentrik atau sumber getaran, desain ayakan, dan desain mekanik secara keseluruhan, termasuk didalamnya terdapat penggabungan fungsi komponen-komponen mekanik lainnya. Desain beban eksentrik ditunjukkan pada gambar 4. Beban eksentrik atau beban tak setimbang dipasang pada poros motor DC. Beban eksentrik tersebut terbuat dari logam besi dengan berat 160 gram. Desain ini digunakan sebagai sumber utama getaran. Pada gambar 5 , arah putaran dari motor getar mempengaruhi arah getaran karena gaya sentrifugal yang diberikan oleh motor getar memiliki vektor arah. Arah getaran cenderang 360o terhadap sumbu $\mathrm{x}$ dan sumbu $\mathrm{y}$, sehingga getaran yang ditimbulkan cenderung atas-bawah dan samping kanan-kiri. Dengan desain tersebut pengayakan biji kopi dapat dilakukan secara maksimal.

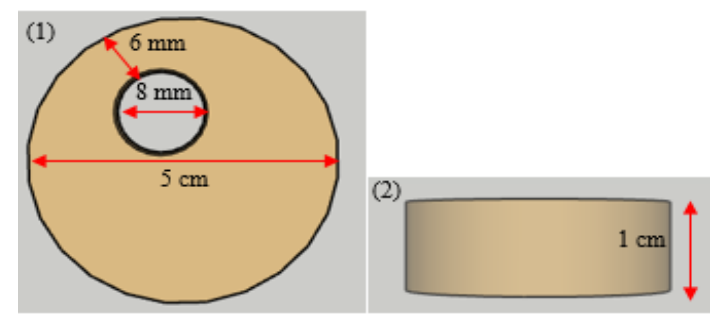

Gambar 4. Beban eksentrik (1) tampak atas (2) tampak depan.

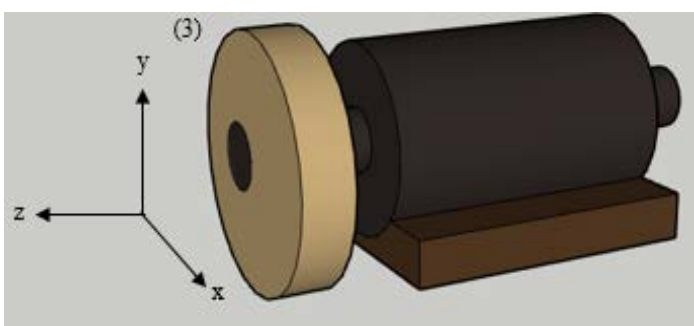

Gambar 5. Desain motor getar.

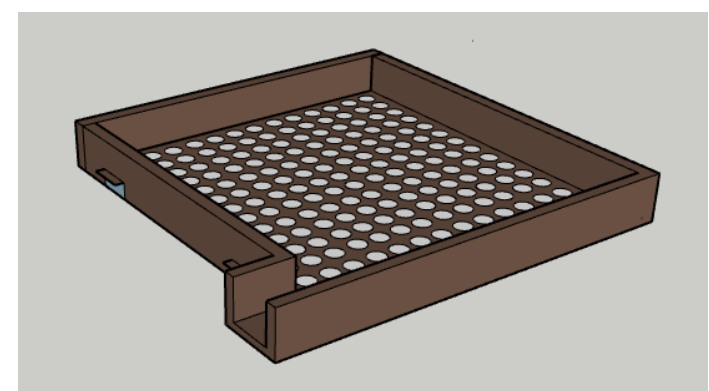

Gambar 6. Desain ayakan tampak tiga dimensi.

Dirancang tiga buah ayakan seperti yang ditunjukkan pada gambar 6. Desain tersebut memiliki panjang $30 \mathrm{~cm}$, lebar 30 $\mathrm{cm}$, tinggi $6 \mathrm{~cm}$. Dari ketiga ayakan tersebut hanya berbeda pada desain ukuran lubang lingkaran, yaitu ayakan pertama memiliki diameter 7,5 mm, kedua memiliki diameter $6,5 \mathrm{~mm}$, ketiga memiliki diameter $5,5 \mathrm{~mm}$.

Gambar 7 menunjukkan desain mekanik secara keseluruhan. Desain tersebut memiliki empat blok yang tersusun secara bertingkat. Blok pertama hingga blok ketiga merupakan ayakan biji kopi dengan diameter lubang yang berbeda di tiap bloknya. Sedangkan blok ke empat (paling bawah) merupakan tempat penampung kotoran-kotoran melekat pada biji kopi atau yang lainnya. Dibagian bawah 
blok ke empat terdapat motor getar yang melekat. Sedangkan penyangga yang berwarna merah merupakan pegas untuk menahan getaran yang dihasilkan. Terdapat kotak hitam dibagian bawah yang berfungsi sebagai tempat penyimpanan komponen elektronik yang digunakan.

\section{B. Desain Elektrik Sistem}

Pada bagian ini akan dilakukan perancangan beberapa komponen elektrik yang digunakan dalam sistem yang ditunjukkan pada gambar 8. Adapun diantaranya adalah perancangan sensor ADXL345, sensor berat modul HX711. ADXL345 menggunakan komunikasi I2C yang dihubungkan pada pin SDA(20) dan SCL(21) arduino due. Untuk catu daya dihubungkan ke sumber tegangan $3,3 \mathrm{~V}$ yang juga dihubungkan ke arduino due. Perancangan load cell dengan menggunakan modul amplifier HX711. Tegangan keluaran yang dihasilkan load cell hanya berkisar mV, oleh karena itu dibutuhkan sebuah amplifier. Keluaran load cell dihubungkan pada kanal A modul HX711.

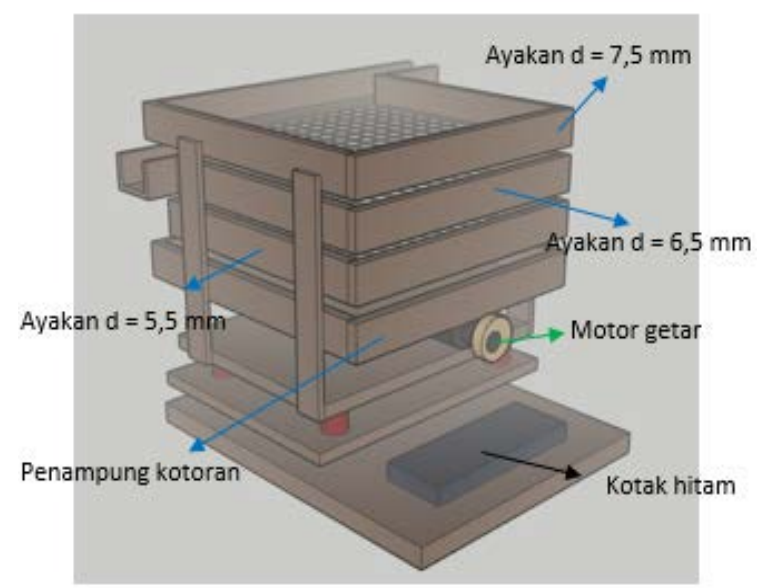

Gambar 7. Desain mekanik keseluruhan.

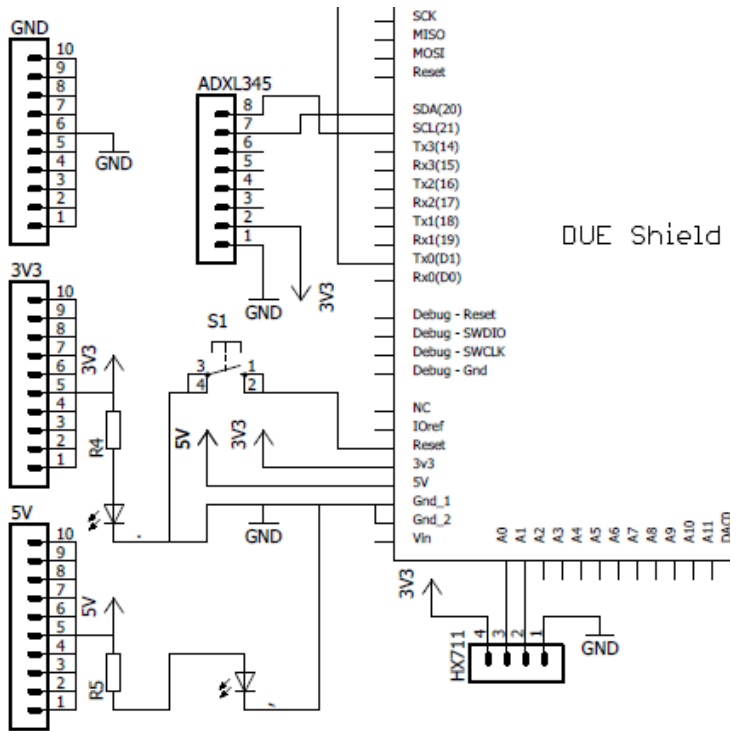

Gambar 8. Koneksi perangkat elektrik sensor percepatan ADXL345 dan sensor berat.

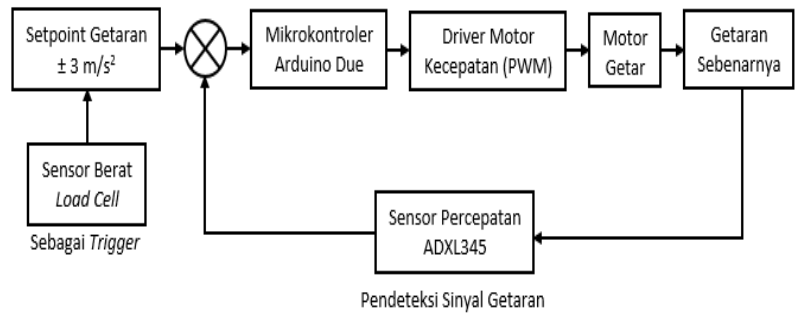

\section{Perancangan Kendali Sistem}

Kendali ini berfungsi untuk mempertahankan getaran atau nilai percepatan yang dihasilkan oleh motor getar agar tetap konstan pada nilai setpoint yang telah ditentukan yaitu $3 \mathrm{~m} / \mathrm{s} 2$ seperti ditunjukkan pada Gambar 9. Nilai tersebut didapatkan dari nilai getaran ketika dapat melakukan pengayakan secara optimal. Sensor berat digunakan sebagai pemicu untuk mengaktifkan proses kendali. Jika sensor membaca beban 300 gram atau lebih maka proses kendali aktif, namun jika kurang dari 300 gram, maka proses kendali mati.

\section{HASIL DAN PEMBAHASAN}

Gambar 10 merupakan hasil realisasi alat sortir biji kopi yang telah didesain. Beberapa tahap pengujian perlu dilakukan untuk mengetahui kinerja sistem ini.

\section{A. Pengujian Sensor Berat}

Pengujian sensor berat dilakukan dengan cara membandingkan hasil pembacaan dari sensor berat dengan timbangan digital yang digunakan sebagai acuan. Pengambilan data juga dilakukan pada tegangan keluaran yang dihasilkan oleh sensor berat. Pengambilan data dimulai dari berat $5 \mathrm{Kg}$ hingga $19 \mathrm{Kg}$. Pada tabel 2 menunjukan hasil pengujian tersebut. Pada gambar 11 menunjukkan hasil dari sensor berat yang mendekati linear.

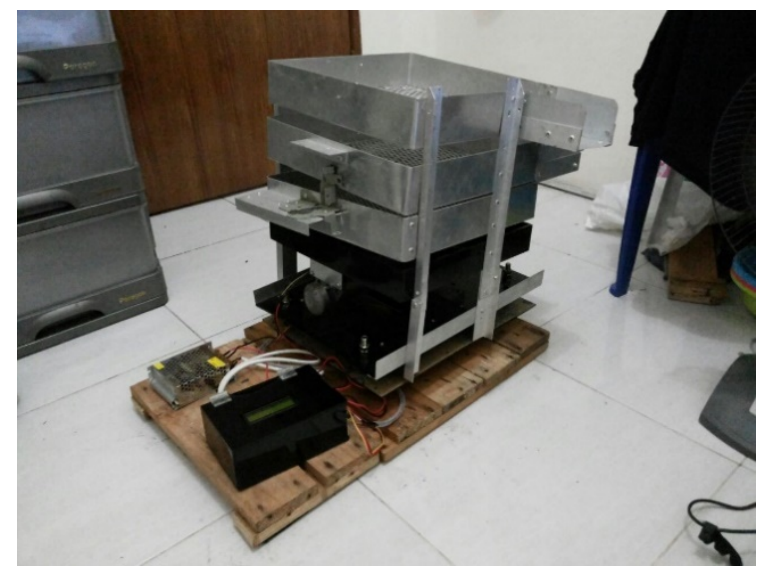

Gambar 10. Hasil realisasi alat sortir biji kopi.

Tabel 2.

Hasil pengujian sensor berat

\begin{tabular}{|c|c|c|c|}
\hline $\begin{array}{l}\text { Timbangan } \\
\text { Acuan (Kg) }\end{array}$ & $\begin{array}{c}\text { Sensor Berat } \\
(\mathbf{K g})\end{array}$ & $\begin{array}{l}\text { Vout } \\
(\mathrm{mV})\end{array}$ & Error (\%) \\
\hline 4,98 & 5,03 & 0,5 & 1,004016 \\
\hline 6,02 & 6,08 & 0,6 & 0,996678 \\
\hline 7,01 & 7,05 & 0,7 & 0,570613 \\
\hline 8,02 & 8,06 & 0,8 & 0,498753 \\
\hline 9,03 & 9,07 & 0,9 & 0,442968 \\
\hline 10,10 & 10,15 & 1,1 & 0,49505 \\
\hline 11,09 & 11,16 & 1,2 & 0,631199 \\
\hline 12,02 & 12,08 & 1,3 & 0,499168 \\
\hline 13,01 & 13,06 & 1,4 & 0,38432 \\
\hline 14,05 & 14,10 & 1,5 & 0,355872 \\
\hline 15,02 & 15,07 & 1,7 & 0,332889 \\
\hline 16,03 & 16,09 & 1,8 & 0,374298 \\
\hline 17,04 & 17,09 & 1,9 & 0,293427 \\
\hline 18,02 & 18,07 & 2,0 & 0,277469 \\
\hline 19,04 & 19,10 & 2,1 & 0,315126 \\
\hline
\end{tabular}




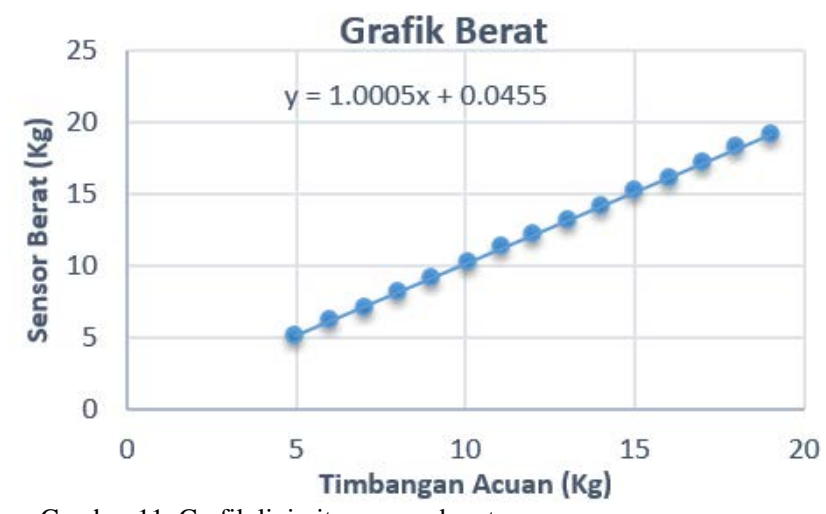

Gambar 11. Grafik linieritas sensor berat.

\section{B. Pengujian Sensor ADXL 345}

Pengujian sensor percepatan ADXL345 ini dilakukan dengan cara memanfaatkan percepatan gravitasi bumi yaitu sebesar 9,8 m/s $\mathrm{s}^{2}$ atau $1 \mathrm{G}$. Kemudian tiap sumbu (x, y, z) dari sensor diuji dengan mengubah-ubah arah vektor percepatannya dengan berpatokan arah percepatan gravitasi yaitu menuju ke bumi (ke bawah). Jika arah sensor berlawanan dengan arah gravitasi bumi maka percepatan yang dihasilkan seharusnya $9,8 \mathrm{~m} / \mathrm{s}^{2}$ sedangkan jika searah bernilai $-9,8 \mathrm{~m} / \mathrm{s}^{2}$. Tabel 3 menunjukan hasil pengujian sensor ADXL345 dengan sudut putar $360^{\circ}$.

Tabel 3.

Hasil pengujian ADXl345 terhadap perubahan sudut

\begin{tabular}{|c|c|c|c|c|c|c|}
\hline \multirow{2}{*}{ Sudut $\left({ }^{\circ}\right)$} & \multicolumn{3}{|c|}{ Alat Ukur Acuan (m/s²) } & \multicolumn{3}{|c|}{ Sensor ADXL345 $\left(\mathrm{m} / \mathrm{s}^{2}\right)$} \\
\hline & $\mathbf{x}$ & $\mathbf{y}$ & $\mathbf{z}$ & $\mathbf{x}$ & $\mathbf{y}$ & $\mathbf{z}$ \\
\hline 0 & 0,11 & 0,12 & 0,03 & 0,20 & 0,16 & 0,43 \\
\hline 45 & 5,01 & 5,04 & 5,03 & 5,04 & 5,16 & 4,64 \\
\hline 90 & 9,84 & 9,83 & 9,83 & 9,78 & 9,93 & 9,92 \\
\hline 135 & 5,09 & 5,03 & 5,04 & 5,15 & 5,12 & 4,73 \\
\hline 180 & 0,07 & 0,03 & 0,02 & 0,19 & 0,16 & $-0,42$ \\
\hline 225 & $-5,04$ & $-5,02$ & $-5,02$ & $-4,89$ & $-5,19$ & $-5,35$ \\
\hline 270 & $-9,78$ & $-9,82$ & $-9,83$ & $-9,66$ & $-9,69$ & $-9,68$ \\
\hline 315 & $-5,03$ & $-5,02$ & $-5,06$ & $-5,12$ & $-4,92$ & $-5,66$ \\
\hline 360 & $-0,03$ & $-0,05$ & $-0,09$ & $-0,10$ & 0,08 & $-0,14$ \\
\hline
\end{tabular}

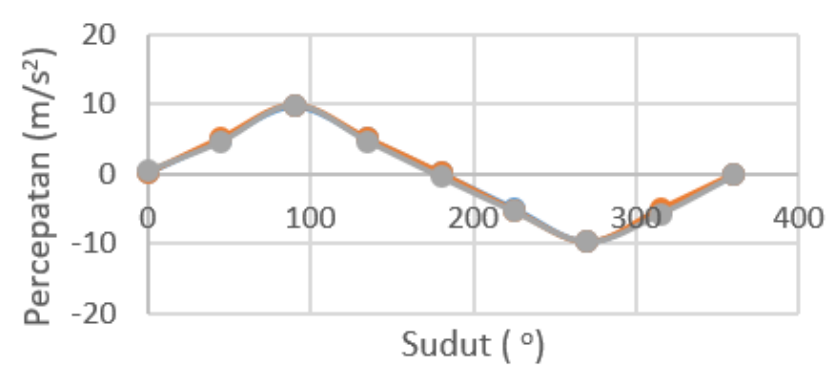

-SumbuX - SumbuY $\longrightarrow$ SumbuZ

Gambar 12. Grafik ADXL345 terhadap perubahan sudut.

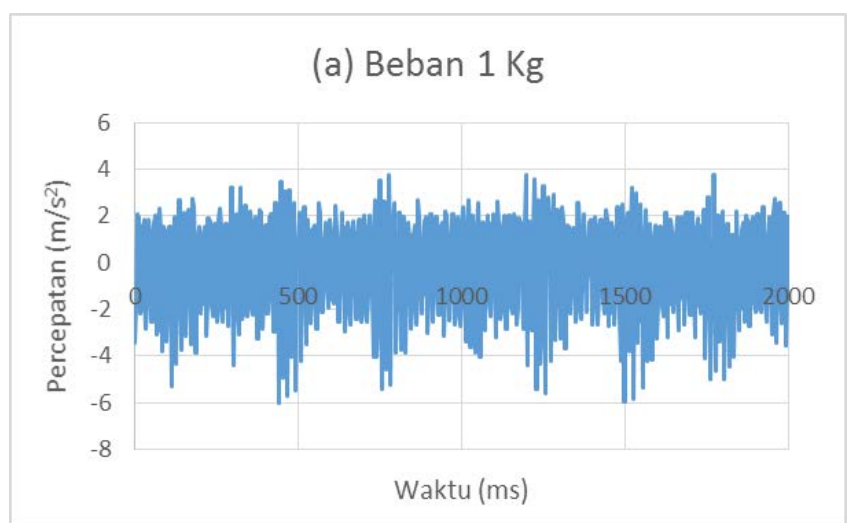

(b) Beban $2 \mathrm{Kg}$

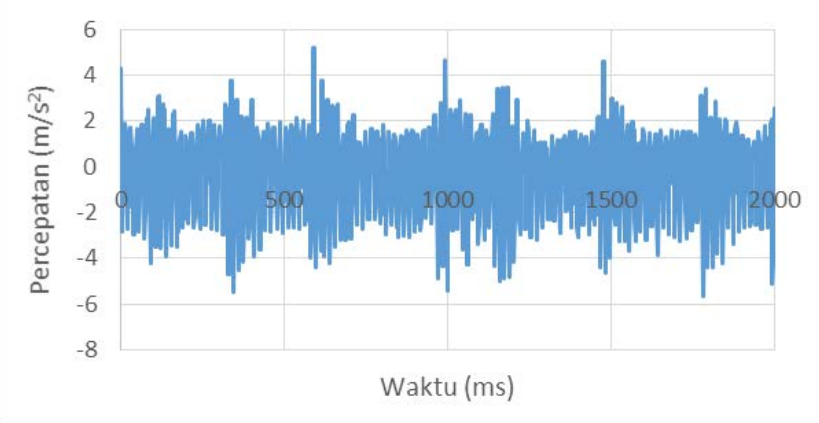

(c) Beban $3 \mathrm{Kg}$

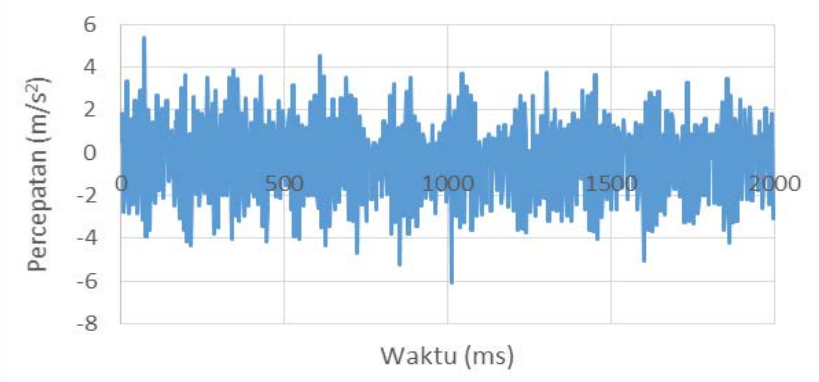

Gambar 13. Hasil pengujian kendali getaran (a) ketika beban $1 \mathrm{Kg}$, (b) ketika beban $2 \mathrm{Kg}$, (c) ketika beban $3 \mathrm{Kg}$.

Gambar 12 menunjukkan bahwa hasil pengujian sesuai dengan teori yaitu ketika sudut $90^{\circ}$ (berlawanan dengan arah gravitasi bumi) percepatan yang dihasilkan mendekati 9,8 $\mathrm{m} / \mathrm{s}^{2}$ untuk tiap sumbu. Sedangkan pada sudut $270^{\circ}$ (searah dengan arah gravitasi bumi) percepatan yang dihasilkan mendekati $-9,8 \mathrm{~m} / \mathrm{s}^{2}$ untuk tiap sumbu.

\section{Pengujian Kendali Getaran}

Pada bagian ini dilakukan pengujian kontrol getaran dengan memberikan beban ayakan yang berbeda-beda. Pada pengujian ini setpoint getaran yang digunakan adalah $\pm 3 \mathrm{~m} / \mathrm{s}^{2}$ dan kendali ini dilakukan dengan mengubah-ubah kecepatan motor getar, sedangkan beban yang digunakan pada pengujian kali ini adalah 1 - $3 \mathrm{Kg}$ dengan kenaikan per $1 \mathrm{Kg}$. Gambar 13 merupakan grafik hasil pengujian kontrol getaran. Pada grafik tersebut terlihat bahwa amplitudo yang dihasilkan hampir mendekati $\pm 3 \mathrm{~m} / \mathrm{s}^{2}$, namun terdapat beberapa sinyal yang terjadi lonjakan.

\section{Pengujian Efisiensi Alat Sortasi Biji Kopi}

Pada pengujian ini berat total biji kopi yang masih tercampur adalah 2000 gram. Pengujian dilakukan beberapa kali sehingga dapat memberikan nilai rata-rata pada tingkat efisiensi dan error nya. Gambar 14 menunjukkan biji kopi yang telah diayak dan telah terklasifikasikan berdasarkan 
ukurannya, serta biji kopi yang masih tersangkut pada alat ayakan. Pada Tabel 4 menunjukkan data-data tersebut dengan beberapa kali pengujian yang telah dilakukan.

Tabel 4.

Hasil pengujian sortasi dengan berat total 2000 gram

\begin{tabular}{cccccc}
\hline \hline \multirow{2}{*}{$\begin{array}{c}\text { Pengujian } \\
\text { ke- }\end{array}$} & $\begin{array}{c}\text { Besar } \\
\text { (gram) }\end{array}$ & $\begin{array}{c}\text { Sedang } \\
\text { (gram) }\end{array}$ & $\begin{array}{c}\text { Kecil } \\
\text { (gram) }\end{array}$ & $\begin{array}{c}\text { Tersangkut } \\
\text { (gram) }\end{array}$ & $\begin{array}{c}\text { Waktu } \\
\text { (detik) }\end{array}$ \\
\cline { 2 - 5 } & 890 & 1000 & 60 & 50 & 142,95 \\
2 & 880 & 950 & 80 & 90 & 154,76 \\
3 & 940 & 910 & 70 & 80 & 161,36 \\
\hline \hline
\end{tabular}

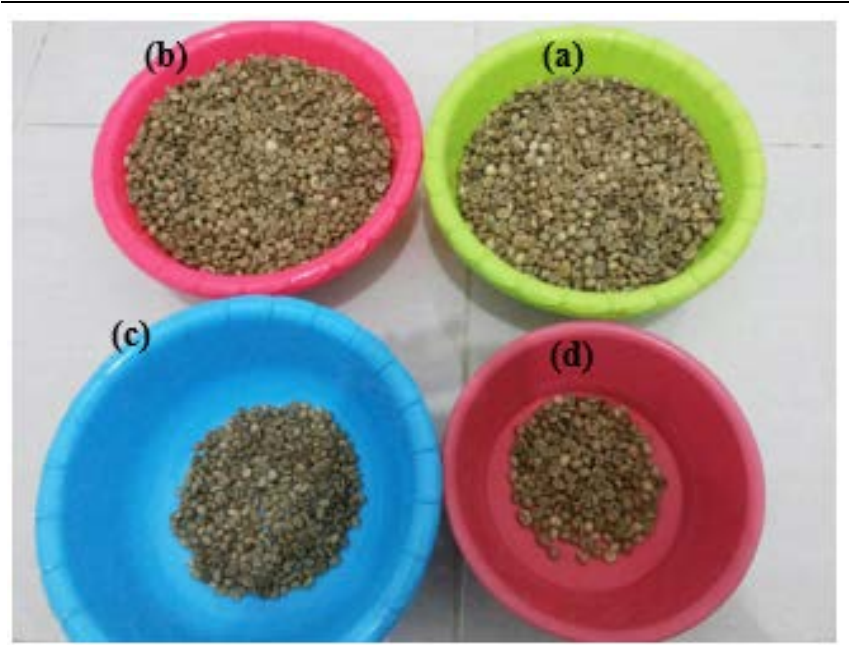

Gambar 14. (a) Biji Kopi Ukuran Besar = 890 gram, (b) Biji Kopi Ukuran Sedang = 1000 gram, (c) Biji Kopi Ukuran Kecil = 60 gram, (d) Biji Kopi yang Tersangkut $=50$ gram

\section{E. Pengujian Error pada Biji Kopi Besar}

Setelah didapat hasil pengujian pada tabel 4, kemudian dilakukan pengujian untuk mengetahui tingkat error pada biji kopi ukuran besar. Pengujian ini dilakukan dengan melakukan pengayakan kembali, namun hanya dilakukan pada biji kopi ukuran besar yang telah diayak tadi. Gambar 15 menunjukkan hasil pengujiannya, sedangkan pada tabel 5 hingga tabel 7 menunjuk-kan hasil pengukuran tingkat error tersebut dengan tiga kali pengayakan yang dilakukan secara berulang-ulang hingga nilai error yang kecil.

Tabel 5.

Pengukuran tingkat error hasil sortasi biji kopi besar pada pengayakan yang ke-1

\begin{tabular}{cccccc}
\hline \hline $\begin{array}{c}\text { Pengujian } \\
\text { ke- }\end{array}$ & $\begin{array}{c}\text { Besar } \\
\text { (gr) }\end{array}$ & $\begin{array}{c}\text { Error } \\
\text { Sedang (gr) }\end{array}$ & $\begin{array}{c}\text { Error } \\
\text { Kecil (gr) }\end{array}$ & $\begin{array}{c}\text { Total } \\
\text { Error (\%) }\end{array}$ & $\begin{array}{c}\text { Waktu } \\
\text { (detik) }\end{array}$ \\
\hline 1 & 890 & 140 & 10 & 16,85 & 68,97 \\
2 & 880 & 120 & 10 & 14,77 & 67,76 \\
3 & 940 & 130 & 20 & 15,96 & 73,32 \\
\hline \hline
\end{tabular}

Tabel 6.

Pengukuran tingkat error hasil sortasi biji kopi besar pada pengayakan yang ke-2

\begin{tabular}{cccccc}
\hline \hline $\begin{array}{c}\text { Pengujian } \\
\text { ke- }\end{array}$ & $\begin{array}{c}\text { Besar } \\
\text { (gr) }\end{array}$ & $\begin{array}{c}\text { Error Sedang } \\
\text { (gr) }\end{array}$ & $\begin{array}{c}\text { Error Kecil } \\
\text { (gr) }\end{array}$ & $\begin{array}{c}\text { Total } \\
\text { Error (\%) }\end{array}$ & $\begin{array}{c}\text { Waktu } \\
\text { (detik) }\end{array}$ \\
\hline 1 & 740 & 55 & 5 & 8,10 & 56,61 \\
2 & 750 & 54 & 7 & 8,13 & 57,69 \\
3 & 790 & 67 & 10 & 9,75 & 60,25 \\
\hline \hline
\end{tabular}

Tabel 7.

Pengukuran tingkat error hasil sortasi biji kopi besar pada pengayakan yang ke-3

\begin{tabular}{cccccc}
\hline \hline $\begin{array}{c}\text { Pengujian } \\
\text { ke- }\end{array}$ & $\begin{array}{c}\text { Besar } \\
\text { (gr) }\end{array}$ & $\begin{array}{c}\text { Error Sedang } \\
\text { (gram) }\end{array}$ & $\begin{array}{c}\text { Error } \\
\text { Kecil (gr) }\end{array}$ & $\begin{array}{c}\text { Total } \\
\text { Error (\%) }\end{array}$ & $\begin{array}{c}\text { Waktu } \\
\text { (detik) }\end{array}$ \\
\hline 1 & 680 & 12 & 1 & 1,91 & 52,36 \\
\hline
\end{tabular}

\begin{tabular}{llllll}
\hline \hline 2 & 689 & 13 & 2 & 2,17 & 53,74 \\
3 & 713 & 14 & 2 & 2,24 & 55,43 \\
\hline \hline
\end{tabular}

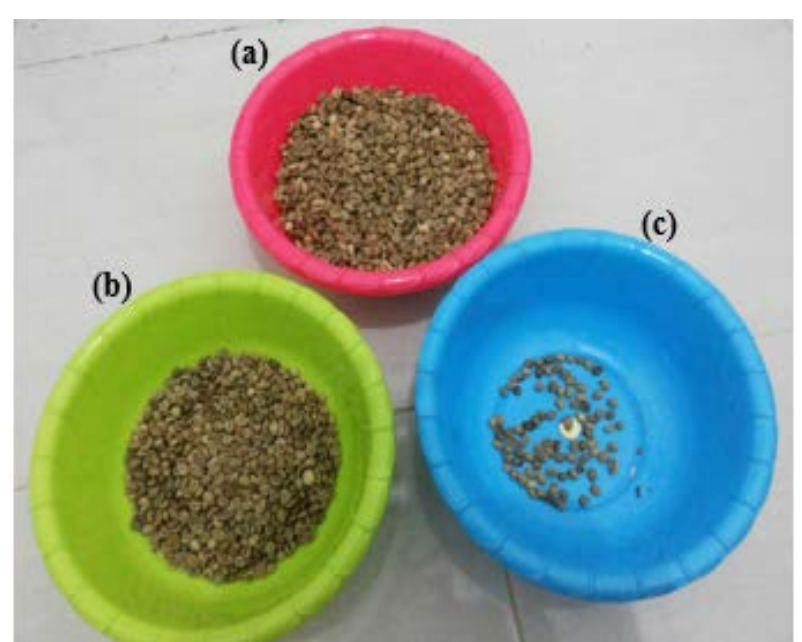

Gambar 15. Mengukur Error pada Biji Kopi Besar, (a) Biji Kopi Besar Sebenarnya = 740 gram, (b) Error Biji Kopi Sedang = 140 gram, (c) Error Biji Kopi Kecil $=10$ gram.

\section{F. Pengujian Error pada Biji Kopi Sedang}

Pengujian yang sama dilakukan pada biji kopi ukuran sedang untuk mengetahui tingkat error. Mengacu pada tabel 4, pengujian dilakukan dengan cara mengayak kembali biji kopi ukuran sedang yang telah diayak tadi. Gambar 16 menunjukkan hasil pengujiannya, sedangkan pada tabel 8 dan tabel 9 menunjukkan hasil pengukuran tingkat error tersebut dengan dua kali pengayakan yang dilakukan secara berulangulang hingga nilai error yang didapat kecil.

Tabel 8.

Pengukuran tingkat error hasil sortasi biji kopi sedang pada pengayakan

\begin{tabular}{ccccc}
$\begin{array}{c}\text { Pengujian } \\
\text { ke- }\end{array}$ & $\begin{array}{c}\text { Sedang } \\
\text { (gr) }\end{array}$ & $\begin{array}{c}\text { Error } \\
\text { Kecil (gr) }\end{array}$ & $\begin{array}{c}\text { Total } \\
\text { Error (\%) }\end{array}$ & $\begin{array}{c}\text { Waktu } \\
\text { (detik) }\end{array}$ \\
\hline 1 & 1000 & 40 & 4,00 & 77,51 \\
2 & 950 & 50 & 5,26 & 73,86 \\
3 & 910 & 30 & 3,29 & 70,98 \\
\hline \hline
\end{tabular}

Tabel 9.

Pengukuran tingkat error hasil sortasi biji kopi sedang pada pengayakan yang ke-2

\begin{tabular}{ccccc}
\hline $\begin{array}{c}\text { Pengujian } \\
\text { ke- }\end{array}$ & $\begin{array}{c}\text { Sedang } \\
\text { (gr) }\end{array}$ & $\begin{array}{c}\text { Error } \\
\text { Kecil (gr) }\end{array}$ & $\begin{array}{c}\text { Total } \\
\text { Error (\%) }\end{array}$ & $\begin{array}{c}\text { Waktu } \\
\text { (detik) }\end{array}$ \\
\hline 1 & 960 & 14 & 1,46 & 74,12 \\
2 & 900 & 11 & 1,22 & 71,39 \\
3 & 880 & 10 & 1,14 & 69,89 \\
\hline \hline
\end{tabular}

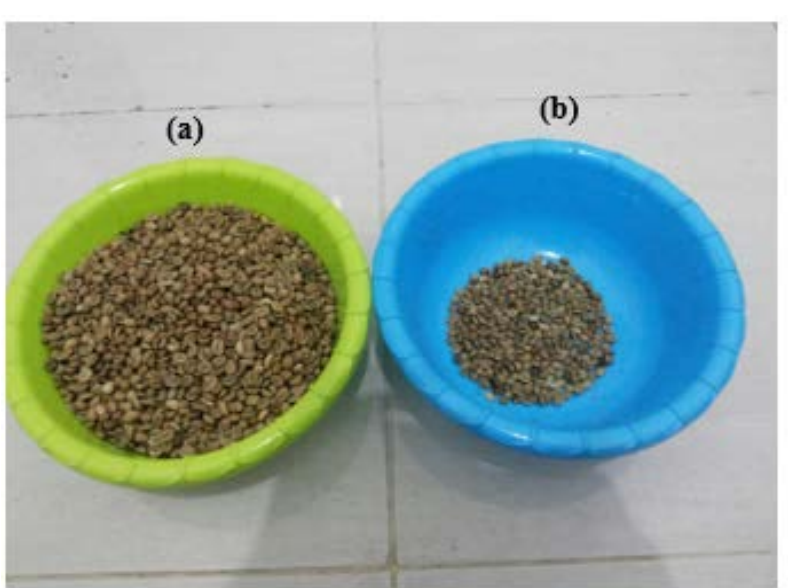

Gambar 16. Mengukur Error pada Biji Kopi Sedang, (a) Biji Kopi Sedang Sebenarnya = 960 gram, (b) Error Biji Kopi Kecil = 40 gram. 


\section{KESIMPULAN}

Sensor percepatan ADXL345 dapat bekerja sesuai dengan percepatan gravitasi bumi ketika memiliki vektor arah yang sama dengan gravitasi bumi ataupun sebaliknya yaitu $\pm 9,8$ $\mathrm{m} / \mathrm{s}^{2}$. Sensor berat dapat bekerja dengan baik terbukti dengan nilai error yang dihasilkan kurang dari $1 \%$. Hasil pengujian kendali getaran terhadap perubahan beban dengan nilai setpoint $\pm 3 \mathrm{~m} / \mathrm{s}^{2}$ menghasilkan getaran yang cukup stabil. Namun masih terjadi lonjakan pada beberapa titik, hal itu dikarenakan kecepatan putar motor getar yang tidak linear berdampak pada proses kendali yang sulit dilakukan. Alat sortasi ini mampu mengayak biji kopi sebesar $2 \mathrm{Kg}$ dengan biji kopi yang tersangkut 50-90 gram dengan membutuhkan pengayakan selama 177,94 - 189 detik pada biji kopi ukuran besar dan selama 140,87 - 151,63 detik pada biji kopi ukuran sedang. Dikarenakan berat biji kopi yang tersangkut mencapai 90 gram, maka pada sistem kendali yang digunakan diatur offset nilai berat sebesar 100 gram.

\section{DAFTAR PUSTAKA}

[1] S. M. Putut and R. Muhammad, "Klasifikasi Kualitas Biji Kopi Menggunakan Pengolahan Citra dan Fuzzy Logic,” in Seminar Nasional Menggagas Kebangkit Komoditas Unggulan Lokal Pertanian dan Kelautan, Fakultas Pertanian Universitas Trunojoyo Madura, 2013, p. 2.

[2] T. D. R., Suwandi, and L. Nuryanti, “Outlook Kopi,” 2016.

[3] Badan Standarisasi Nasional (BSN), "SNI 01-2907-2008 Biji Kopi," 2008.

[4] M. Rivai and M. Hery Purnomo, "GA-SVC Based Search Applied for Optimization of Image Features Subset in Quality Estimation System of Bulk Green Coffee Bean,” vol. 10, no. 22, 2015.

[5] F. Winjaya, M. Rivai, and D. Purwanto, "Identification of Cracking Soung During Coffe Roasting Using Neural Network,” in International Seminar on Intelligent Technology and Its Application Institut Teknologi Sepuluh Nopember Surabaya, 2017, p. 1.

[6] Y. Chen, "Vibration Motor Application note," 2013.

[7] A. Devices, “Three-Axis, $\pm 2 / 4 / 8 / 16 g$ Digital Accelerometer,” 2008.

[8] S. K. Risandriya, M. Rivai, and D. Purwanto, “Aplikasi sensor Micro Electro Mechanical system (MEMS) sebagai identifikasi ketidaknormalan pada conveyor belt system,” 2011.

[9] P. T. Asri, M. Rivai, and T. Tasripan, "Sistem Pendeteksi Kepatahan Mata Bor pada Mesin Cetak PCB Berdasarkan Analisa Getaran Spindle Menggunakan Teensy Board,” J. Tek. ITS, vol. 7, no. 1, pp. 98-103, Mar. 2018.

[10] P. H. Thakkar and P. DPatel, "Performance Evaluation of Strain Gauge Based Load Cell to Improve Weighing Accuracy,” Int. J. Latest Trends Eng. Technol., pp. 1-3. 